\title{
'Azrâ'u Câkartâ Adlı Romanın Türkçe Çevirilerinin Çeviri Stratejileri Açısından İncelenmesi
}

\author{
Musa YILDIZ* \\ Halil İbrahim ŞANVERDİ **
}

Öz

Çeviri sırasında kaynak ve hedef dil normlarının yanında çevirmenlerin dikkat etmesi gereken diğer bir husus kaynak metnin türüdür. Özellikle yazın çevirisinde karşılaşılan zorluklar göz önüne alındığında çevirmenlerin çeviriye başlamadan önce çeviri alanına dair bazı bilgilere sahip olması gerekmektedir. Roman, öykü, tiyatro ya da şiir çevirisinin hedef dilde nasıl yansıtıldığı çok önemlidir. Çünkü çevirmenin çeviri sırasındaki tercihleri hedef metnin okunabilirliğini etkileyen en önemli unsurdur. Klasik ve dini eser çevirilerinin yanında son yıllarda edebi alanda Arapçadan Türkçeye yapılan çeviri eserler incelendiğinde ilk sırayı roman türü almaktadır. Arap edebiyatından başta Nobel ödüllü Necîb Mahfûz olmak üzere başka yazarların da edebi eserleri Türkçeye aktarılmaktadır. Necîb el-Kîlânî, 1931-1995 yılları arasında yaşamış ve hayatına otuza yakın romanıyla birlikte öykü, deneme ve bilimsel bilgi içeren birçok eser sığdırmıştır. Yazdığı romanlarla Mısır'da çeşitli ödüllere layık görülen yazarın Türkçeye çevrilmiş 10'dan fazla eseri bulunmaktadır. Çalışmamızda Türkçeye farklı çevirmenler tarafından aktarılan Kîlânî'nin 'Azrâu Câkartâ adlı romanı çeviri stratejileri açısından karşılaştırmalı olarak değerlendirilmiştir. Çalışmanın ilk bölümünde çeviri, çeviri stratejileri, romanın konusu, roman yazarı hakkında bilgi verilmiş, ikinci bölümde de kaynak ve hedef metinlerden alınan örnekler karşılaştırmalı olarak incelenmiştir. Çalı̧̧ma kapsamında Arapçadan Türkçeye çevrilen eserlerde ne gibi yöntemlere başvurulduğu ortaya konulmuştur. Çalışmanın çevirmenlere çeviri sırasında hangi çeviri stratejilerini kullanabilecekleri hakkında bilgi vereceği düşünülmektedir.

Key Words: Arapça-Türkçe Çeviri, Çeviri Stratejileri, Yazın Çevirisi, Necîb el-Kîlânî.

\footnotetext{
* Prof. Dr., Gazi Üniversitesi, Gazi Eğitim Fakültesi, Arap Dili Eğitimi Anabilim Dalı. Ankara. Türkiye. Elmek: musayildiz@hotmail.com https://orcid.org/0000-0002-5274-9481

** Arş. Gör., Çankırı Karatekin Üniversitesi, Edebiyat Fakültesi, Arap Dili ve Edebiyatı Anabilim Dalı. Çankırı.Türkiye. Elmek: halilbrahim@hotmail.com https://orcid.org/0000-0002-7093-7099
} 


\title{
Analysis of Turkish Translation of The Novel Azra Jakarta in Terms of Translation Strategies
}

\begin{abstract}
Along with the source and target language norms that translators should pay attention to the kind of source text during translation. Especially for difficulties in the literary translation, translators should have some knowledge of translation before starting translation. It is very important how a translation of a novel, story, theater or poetry is reflected in the target language. Because the translator's preferences are the most important factor affecting the readability of the target text. In addition to the translation of classical and religious works, the novel translation is first in the translation works from Arabic to Turkish in the literary field in recent years. The literary works of other writers, especially with Nobel Prize winner Najib Mahfuz from Arabic literature, are translated to Turkish. Najib al-Kilani lived between 1931 and 1995 and wrote stories, essays and academic works with almost thirty novels. He was awarded several prizes in Egypt for his novels and more than ten novels translated into Turkish. In this study, Kilani's Azra Jakarta novel which was translated into Turkish by different translators was analyzed comparatively in terms of translation strategies. In the first part of the study is given information about translation, translation strategies, the subject of the novel, the novelist and in the second part analyzed comparatively samples taken from the source and target texts. In this study it is revealed which strategies are used in translations from Arabic to Turkish. It is thought that this study will give information to translators about which strategies to use during translation.
\end{abstract}

Keywords: Arabic-Turkish Translation, Translation Strategies, Literary Translation, Najib al-Kilani. 


\section{Extended Summary}

Translation is one of the most important activities providing intercultural communication. Because there are societies that speak different languages from past to present, translation activity is always needed. After that, it is a fact that translation will be needed in order to ensure international communication in a globalizing world. Translation is a necessary activity for intercultural social and economic interaction in addition to cultural exchange.

Literary translation differs from other text types in the classification of translation types. The translation of a literary text is one of the most complicated of the types of written translation. Because in these text types have meaning beyond the first meanings of words and sentences. Therefore, translators face various difficulties especially in the translation of literary texts. These difficulties can be minimized by various methods. If translators have knowledge about these methods, target texts can be more intelligible and readable. Because the translation strategies preferred by the translators are very effective on the intelligibility and readability of the target text.

In the scope of the study the translations of the novel Azra Jakarta of Najib Kilani's, whose some works were translated from Arabic to Turkish, was examined comparatively in term of which translation strategies were preferred by the translators in their translations. The aim of our study is to evaluate the effects of these strategies on the readability of target language texts by revealing the strategies which are preferred in translating from Arabic to Turkish. Besides that, some strategies that may be an alternative to the methods preferred by translators were also proposed.

Social, economic and historical relations between Arabs and Turks are based on a long past. Therefore, translation activity between these two cultures is inevitable. Previously, translation activity between these two languages focused on religious texts and classical works, and then this activity gained momentum in the field of literary translation. When the Egyptian writer Najib Mahfouz received the Nobel Prize, the translation activity between these two cultures increased 
more. Generally, the works of writers such as Najib Mahfouz and Khalil Gibran were translated to Turkish from a different language except for Arabic. However, in recent years there has been an increase in the translation of literary works from Arabic. When we look at the translated writers from Arabic to Turkish, the writers such as Abdel Hamid Gouda al-Sahhar, Adonis, Jurji Zaydan, Khalil Gibran, Mahmoud Darwish, Najib Mahfouz, Najib Kilani, and Nizar Qabbani come into prominence. When we look at the names that translate from Arabic to Turkish, Ibrahim Demirci, Mehmet Hakkı Suçin, and Metin Fındıkçı are at the forefront in the field of poetry. But, in novel and story translation, there are names like Adem Yerinde, Ali Nar, Erdinç Doğru, Erkan Avşar, Halim Öznurhan, Hülya Afacan, Hüseyin Yazıcı, Musa Yıldız, Rahmi Er, and Selahattin Hacığlu.

While there are studies on critical analysis of literary translations from any foreign language to Turkish, the number of literary translation criticism studies from Arabic to Turkish is quite low. However, it is thought that critical studies on translations from any foreign language to Turkish will increase the quality of translations between two languages. In our study, firstly theoretical definitions have been formed by considering translation definitions, literary translation, and translation strategies. After giving brief information about source text and author, samples selected from source text were compared with target texts. It was dwelled on that the translators preferred which translation strategies in their translations. In addition, for some examples, was suggested that it is possible to create more readable texts in the target language preferring a different strategy. Besides that, in the conclusion of the study, the target texts were evaluated based on Toury's equivalence.

As a result of the study, it is seen that translators generally preferred a translation based on the source text. So, the readability and comprehensibility of the target texts have been adversely affected by the methods preferred by the translators. Especially in literary translations, it is expected from translators to create a similar effect of the effect of the source text on the reader. For both literary translations and other translations, it is concluded that translators having some theoretical knowledge in addition to knowing both languages, it will be highly effective on the readability of translation text. In addition, it will be useful to have a review by an expert in both languages in order to increase the readability and intelligibility of literary texts translated to Turkish from any foreign language. 


\section{Giriş}

Çeviri, kültürler arası iletişimi sağlayan, farklı dilleri konuşan insanların birbirlerinden haberdar olmasına imkân veren dilsel bir etkinliktir. Her çeviri bir bakıma başka bir zamana, mekâna ya da kültüre yapılan yolculuktur. Günümüzde çeviri, toplumların, ülke yönetimlerinin neredeyse vazgeçemeyeceği zorunlu bir etkinlik halini almıştır. Çevirinin vazgeçilemeyecek bir etkinlik olduğunu dile getiren Stolze, insanlar farklı diller kullandıkları sürece çevirinin var olacağını vurgulamaktadır. Siyasi ve toplumsal iletişimde ve siyasal gücün yayılmasında olduğu gibi, huzurlu seyahat ortamında ama özellikle felsefenin, bilimin, edebiyatın ve dinin aktarımında dil engelinin aşılması için çevirinin her daim insanın vazgeçilmez etkinliklerinden biri olacağını belirtmektedir (Stolze, 2013, s. 17).

Araplarla Türklerin derin tarihi bağlarının yanında uzun yıllar Osmanlı Devleti'nin Arap coğrafyasına hükmetmesi iki toplum arasındaki kültür alışverişini zorunlu kılmıştır. Her iki toplum siyasi, ekonomik ve kültürel anlamda birbirinden istifade etmiştir. Arapça ve Türkçe arasındaki çeviri hareketliliği tarihi bağların da etkisiyle oldukça eskiye dayanmaktadır. Gürçağlar, 13. ve 14. yüzyıllarda Osman11 İmparatorluğu'nda ilk yazılı çevirilerin Arapça ve Farsçadan yapıldığını bu çevirilerin Osmanlıcanın gelişimine katkı sağladığını, edebiyatta Farş̧a önde gelse de dini metinlerle tıp ve fen bilimleri alanındaki çevirilerde Arapçanın kaynak dil olarak kullanıldığını belirtir (T. Gürçağlar, 2016, s. 18). Arapça ile Türkçe arası çeviri hareketliliği klasik dönem eserleri ve dini eserler üzerinde yoğunlaşmışken belirli bir dönem sonra modern dönem edebi eserlerin de Türkçeye aktarılma çabası başlamıştır. Dağbaşı, Araplar ve Türkler arasındaki kültürel bağın oluşmasında en önemli faktörlerden birinin çeviri olduğunu ve günümüzde edebi çevirilerin önemli bir yer teşkil ettiğini belirtir (Dağbaşı, 2017, s. 181). İki kültür arasındaki çeviri hareketliliği Mısırlı yazar Necîb Mahfûz'un 1988 yılında Nobel edebiyat ödülünü almasıyla ivme kazanmıştır. Ancak Türkçede yayımlanmış olan Mahfûz’un birçok romanı İngilizceden dilimize aktarılmıştır. Yıldız'ın eserlerin isimleri ve çevirmenleri hakkında bilgi verdiği çalışmasında, Mahfûz’un Türkçeye aktarılan romanla- 
rının çoğunluğu, Arapça dışında bir yabancı dil aracılı̆̆ıyla dilimize çevrilmiştir (Yıldız, 2009, ss. 17-28, 2017, ss. 81-82). Bununla birlikte Arapçadan Türkçeye yapılan edebi çevirinin, Arapçadan diğer yabancı dillere yapılan çeviri eserlerle k1yaslandığında nicelik olarak az olduğunu söylemek mümkündür. Modern Arap edebiyatından Türkçeye çevrilen isimlere bakıldığında Abdulhamid Cûde es-Sahhâr, Corcî Zeydân, Halîl Cibrân, Mahmûd Dervîş, Necîb el-Kîlânî, Necîb Mahfûz ve Nizâr Kabbânî gibi edebiyatçılar öne çıkmaktadır.

\section{Çeviri}

Herhangi bir söz veya metnin bir dilden başka bir dile aktarılması olarak tanımlanan çeviri kavramı farklı dillerin varoluşundan itibaren etkinliğini sürdürmektedir. Yalçın çeviriyi, toplumların yaşamında hayatî bir rol oynayan ve toplumlar arasındaki bilgi alışverişinde çağın vazgeçilmez bir etkinliği ve bir dildeki bildirilerin anlam ve biçem yönünden eşdeğerlik sağlamak suretiyle bir başka dile aktarılması işlemi ve bunun sonucunda ortaya çıkan ürün olarak tanımlar (Yalçın, 2015, s. 9,11). Göktürk de (2016), başka dillerin tanımladığı, başka dünyaların tanıtılması ve değişik toplulukların, ulusların, bilim, sanat, düşünce alanındaki çabalarını birbirleriyle paylaşabilme yolu olan, diller ötesinde bir ortak dil, dillerin dili olarak tanımlamaktadır (s. 15). İşler ve Yııldız, bilim ve teknolojinin gelişimiyle gittikçe küçülen dünyada çeviri olgusunun hem dil içi hem de diller arası düzeyde iletişimin ayrılmaz bir parçası olarak önemini ve güncelliğini koruduğunu vurgulamaktadır (İşler ve Yıldız, 2008, s. 17). Çeviri, kapalı kapıları açabilecek özelliğe sahip bir anahtar niteliğindedir. Özellikle dil öğretiminde önemli bir yere sahip olan çeviri, medeniyetlerin kültürel, sanatsal ve ticari anlamda gelişimine büyük katkı sunmaktadır. Birçok ülkenin edebiyatının gelişiminde çeviriden ve çeviri aracılığıyla bu alanda elde edinilen kazanımlardan söz etmek mümkündür. Örneğin edebiyat alanında önemli bir yeri olan roman türünün Türk ve Arap edebiyatına çeviri aracılığıyla girdiğini söyleyebiliriz.

Dünyada yaklaşık yedi bin dilin var olduğu (Ethnologue Languages of The World, 2018) bilgisine dayanarak, aslında çevirinin çok önemli bir görev üstlendiğini söylemek mümkündür. Çünkü bir insanın tüm bu dilleri bilmesinin imkânsızlı̆̆ gerçeği, çeviri olmadan birçok bilgi ve kültür alışverişinin eksik kalacağını açıkça 
göstermektedir. Grossman, çevirinin olmaması durumunda dünya üzerinde bin tane dil olduğu varsayılsa bile on dil bilen bir dehanın dahi 990 dilde yazılanlardan mahrum kalacağını ifade eder (Grossman, 2017, s. 21, 22).

$\mathrm{Bu}$ önemli görevi üstlenen kişi yani çevirmen, kaynak ve hedef dil metinleri arasında eşdeğer metin oluşturmaya çabalayan bir uzmandır. Çevirmeni sadece kaynak dil mesajını hedef dile aktarmakla görevli bir kişi olarak nitelemek yüzeysel bir bakış açısının göstergesidir. Raková çevirmeni yetkin bir dilbilimcinin üstünde görür. Çevirmenin, çeviriyi kaynak dilin kültürel ve sezgisel açıdan değerlendirmesini ve bunun hedef dil dizgesinde tutacağı yeri göz önünde bulundurması gereken bir kişi olduğunu belirtir (Raková, 2016, s. 30). Çevirmen özellikle yazın çevirisinde kaynak metnin okunabilirliğini hedef dilde de oluşturmaya çabalamalıdır. Anamur, çevirmeni geniş bir bilgiye sahip, yazarın yapıtını çok iyi bilen, onun düşüncesini, amacını, söylemek istediğini anlayan, yorumlayan ve bu yapıtı bir hedef dilde, farklı bir bağlamda, anlamsal, anlatımsal, biçemsel ve etkisel özelliklerini yitirmesine izin vermeden anadilindeki doğallıkla, sanki yazar yapıtını hedef dilde yazıyormuşçasına, ancak hedef metni ulusallaştırmadan eşdeğerli olarak üreten kişi olarak tanımlar (Anamur, 1998, s. 2).

Çeviri tanımlarında ve çeviriye dair söylemlerde eşdeğerlik kavramıyla sıkça karşılaşılmaktadır. Eşdeğerlik, kaynak ve hedef metin arasında oluşturulmas1 beklenen bir olgudur. Yani kaynak dil metni içeriğinin belirli ölçütler 1şığında hedef dilde oluşturulmasıdır. Aktaş, eşdeğerliğin kaynak ve hedef dil metni arasında dilbilgisi yönünden yeterli ölçüde denklik kurma ve bununla birlikte kaynak dildeki bir mesajın anlam, işlev, üslup, iletişim ve kültürel bakımdan hedef dilde en doğal biçimde yansıtma anlamına geldiğini vurgular (Aktaş, 1996, s. 94). Nida ve Taber'e göre çevirmen kaynak metnin öncelikle içeriğini sonra da biçemini göz önüne alarak yani 'biçimsel eşdeğerliği', sonra da alıcıya yönelip hedef dilde iletinin doğallığını yani 'dinamik eşdeğerliği' sağlamalıdır (Nida ve Taber, 1982, s. 24). Çeviride anlamsal ve iletişimsel çeviri kavramlarını kullanan Newmark da, çeviri sürecinde eşdeğerliği yakalamak için metin türü ve içeriğinin yanında okur kitlesinin özelliklerini göz önünde bulundurmak gerektiğini vurgular (Newmark, 1988, s. 83; Özyön, 2014, s. 33). 


\section{Yazın Çevirisi}

Mounin çeviriyi dini çeviriler, edebi çeviriler, şiir çevirileri, çocuk edebiyatı çevirisi, tiyatro çevirisi, sinema çevirisi ve teknik çeviri gibi çeşitli türlere ayırmaktadır (akt. Reiss, 2000, s. 22). Mansûr ise, çeviriyi bilimsel çeviri, edebi çeviri ve dini çeviri olmak üzere üç başlıkta inceler. Öykü, roman, tiyatro ve çevirisi en meşakkatli olan şiir çevirisini edebi çeviri içerisine alarak edebi çevirinin anlamdan çok sözün etkisine ve üslubun derinliğine odaklandığını vurgular (Mansûr, 2006, s. 31).

Genel itibariyle yazın çevirisi, teknik çeviri ve bilgilendirici metin çevirileri gibi diğer çeviri türlerinden ayrı tutulmaktadır. Çünkü yazın alanının kendine has estetik, anlam ve biçimsel özellikleri mevcuttur. Yazınsal metinlerde kelimeler ve cümleler ilk anlamlarının ötesinde anlam taşırlar. Birçok sanatsal kullanım yazınsal metinlerde kendisini gösterir. Bu yüzden dilsel ve kültürel olarak birçok öğe içeren ve etkileyici ifade tarzlarının yer aldığ yazınsal metinlerin çevirisi ayrı bir yere sahiptir. Aksoy, yazın çevirisinde çevirmenin bazen yazınsal metni çeviremeyecek duruma düştüğünü, bunun da yazın dilinin günlük dil ve konuşmalardan çok farklı anlamlar ve yapılar içerdiğiyle yakından ilişkili olduğunu belirtir. Yazın metninin yaratıcılık ve özgünlük boyutları bu türün çevirisini de güçleştirmektedir (Aksoy, 2002, s. 57). Schleiermacher, yazınsal metin çevirilerinde iki yaklaşımın varlığından bahseder ve çevirmenin çeviri metni okura götüreceğini yani yerelleştirebileceğini ya da okuru metne götüreceğini yani metni yabancilaştırabileceğini vurgular (akt. Snell-Hornby, 2006, s. 10). Göktürk de, her çevirinin çevirmenin parmak izlerini taşıdığını ancak çevirmenin kaynak dil ile çeviri dilini kullanabilme gücü, zihinsel çözümleme, yorumlama, çağrıştırma yetisi gibi özelliklerinden dolayı bu izlerin en çok görüldüğü alanının yazın yapıtlarının çevirisi olduğunu ifade eder. Ayrıca metinlerin yalın ve karmaşık olarak ayrıma gitmesi söz konusu olsa şüphesiz en karmaşık, çevirisi en çok sorun çıkaran, çevirmeni en çok zorlayan ve onu ele veren metinlerin yazın metinleri olduğunu savunur (Göktürk, 2016, s. 104, 105). Yazınsal metinlerde söz oyunları, mecazi kullanım, sözcüklerin yan anlamlarının kullanımı en üst düzeyde iken teknik ya da nesnel alan olarak nitelenecek herhangi bir çeviride aynı durum söz konusu değildir. Yazınsal metinler hem açıkça dile getirilen düşüncelerle hem de gizli denebilecek anlatımlarla doludur. Yazınsal metin yazarının biçemiyle ilgili olarak bu tür metinlerde eksiltili, karmaşık, devrik cümleler görmek mümkündür. 


\section{Çeviri Stratejileri}

Çeviride kaynak dildeki mesajı hedef dile aktarırken çevirmenin birçok zorlukla karşılaşması gayet doğal karşılanan bir durumdur. Kaynak ve hedef dil arasındaki doğal farklılıklardan kaynaklı durumları farklı yöntemlerle çözmek ve kaynak dildeki iletinin etkisinin bir benzerini hedef dilde de oluşturmak çevirmenin görevlerindendir. Kaynak ve hedef dil arasında ne kadar çok farklılık olsa da her metnin belirli stratejiler kullanılarak çevrilmesi mümkün görünmektedir. Çeviri stratejileri, çeviri işlemi sırasında çevirmenlerin çeviri sorunlarını çözmek ve çeviri eşdeğerliğinde istenen seviyeye gelmek için, izlediği yollar ve kullandıkları yöntemlerdir. Çeviri stratejileri bir bakıma çevirmenin çeviri sırasındaki yardımcılarıdır. Suçin, diller arası çevirinin mümkün olmasına rağmen, çevirmenin karşılık bulamama sorunuyla her zaman karşı karşıya kalabileceğini ve bu durumda da çevirmenin sorunu birtakım stratejiler yoluyla telafi etmeye çalıştı̆̆ını belirtmektedir (Suçin, 2013, s. 30). Çeviri işlemi sırasında çevirmenlerin karşılaştıkları zorlukları aşarak kaynak metin ve çeviri metin arasında uygun eşdeğerliği kurmak için başvurdukları stratejiler çeviribilimciler tarafından isimlendirilmiştir. Vinay ve Darbelnet, çeviri stratejilerini şu başlıklarda toplamıştır (Munday, 2001, s. 56-59):

1. Ödünç Alma (Borrowing): Kaynak metinde geçen kelimenin hedef metne çevrilmeden kaynak metindeki şekliyle direkt olarak aktarılmasıdır. Hedef dilde yer almayan sözcükler için kullanılabileceği gibi hedef metinde yabancılık etkisi oluşturmak için de kullanılabilir. Yazıcı, ödünçlemenin yabancı sözcüğün doğrudan aktarımı şeklinde olabileceği gibi Türkçe sesletime uygun şekilde çevrilmesinin de bu yönteme girdiğini belirtir. (Yazıc1, 2011, s. 65).

2. Öykünme (Calque): Kaynak dildeki bir sözcük ya da yap1nın hedef dile sözcügüü sözcügüne aktarımıdır. Vinay ve Darbelnet, ödünç alma ve öykünme stratejisi ile hedef dile geçen kelimelerin zamanla hedef dile yerleşebileceğini belirtmektedir.

3. Sözcüğü sözcü̈̆̈̈ne çeviri (Literal Translation): Birebir çeviri işlemi olarak da adlandırılır. Bu stratejide hedef dilin kullanımına dikkat edilir ancak kaynak metnin bütünlüğüne herhangi bir müdahalede bulunulmaz. Anlama değil biçime odaklanılır. Eksiltme 
veya ekleme yapılmaz. Edebi türlerin çevirisinde yeterli bir yöntem olmayabilir.

4. Yer değiştirme (Transposition): Kaynak metinde yer alan öğelerin anlamı değişmeden yer değiştirmesi yani hedef dile aktarımıdır. Bu durum zorunlu ya da tercihen olabilir. Fiil olan öğe, hedef dile aktarılırken isim olarak veya kaynak dildeki zarf, hedef dile fiil olarak aktarılabilir.

5. Değiş̧tirme (Modulation): Bu değişim kaynak dildeki anlamın farklı bir yapıyla hedef dile aktarılması olarak açıklanabilir. Berk, bu yöntemin hedef metindeki bir bölümün bakış açısını değiştirerek ya da bir açıklama getirerek yeniden düzenlenen çeviri işlemi olduğunu belirtir (Berk, 2005, s. 138).

6. Eşdeğerlik (Equivalence): Bu terim kaynak ve hedef dilin aynı durumu farklı üslup ve yapıyla vermesiyle ilgili olarak kullanılır. Eşdeğerlik özellikle deyim ve atasözü çevirilerinde kullanılan bir stratejidir. Bir dilde var olan deyimin çevrilecek dilde nasıl ifade edildiğini bilmek bu açıdan önemlidir. Doğru, Arapça 'اختلط الحابل بالنابل، deyiminin sözlük anlamının 'ağ kuran kişi ile ok atan birbirine karıştı' olduğunu ancak bunun Türkçe deyimsel ifadesi 'sapla saman birbirine karıştı' olarak çevrilmesinin doğru bir çeviri olacağını vurgulamaktadır (Doğru, 2011, s. 73).

7. Uyarlama (Adaptation): Kaynak kültürde bulunan bir durumun hedef kültürde birebir aynısının bulunmamasında kullanılan işlemdir. Çeviri işleminde hedef kültürün özellikleri dikkate alınır. Berk, hedef kitlenin beklentilerini karşılayabilmek için kaynak dildeki bir eseri erek kültürün ya da belirli bir hedef kitlenin koşullarına uygun şekilde gerçekleştirilen çeviri işlemi olarak açıklar (Berk, 2005, s. 157).

Mona Baker da, çevirmenlerin eşdeğerliliği sağlamak için çeşitli stratejilere başvurduklarını belirterek bu stratejileri şu başlıklar altında toplamıştır (Baker, 2011, ss. 23-47): 
1. Genelleştirme - Üst Anlaml (Superordinate): Genelleştirme stratejisi, kaynak metinde yer alan bir ifadenin hedef metne aktarllırken kendisinden daha genel anlam içeren bir ifade ile aktarılması işlemidir. Dickins, Arapçadaki "خال وعام 'yani amca ve dayı' gibi ifadelerin İngilizceye 'uncle' ifadesi ile çevrildiğinde hedef dildeki bu ifadenin Arapçadaki özel ifadelere göre daha genel bir anlam içerdiğini belirtmektedir (Dickins, Hervey ve Higgins, 2017, s. 77).

2. Özelleştirme - Alt Anlamll: Kaynak dildeki daha genel yani üst anlamlı bir ifadenin ya da sözcüğün hedef dile aktarılırken duruma göre daha alt anlamlı yani özel anlamlı bir ifade olarak çevirme işlemidir. Dickins, Arapçada geçen "صندوق" kelimesinin genel bir ifade olduğunu belirtir. Bunu İngilizceye aktarırken bağlamdaki duruma göre mesela sokak arasında çöp atma eylemi için kullanılacak ise kaynak metindeki bu kelimenin İngilizcedeki ‘bin' kelimesi ile karşılanması, fakat birinin kitaplarını bir kutuya koyması şeklinde bir anlam var ise 'box' kelimesinin kullanılması gerektiğini vurgular (Dickins ve diğerleri, 2017, s. 77).

3. Kültürel İkâme (Cultural Substitution): Kültür özellikli bir öğe veya ifadeyi hedef dilde aynı anlamı içermeyen fakat hedef dil okuyucusunda aynı etkiyi bırakmaya ve benzer bir bağlamı çağrıştırmaya sahip hedef dil öğesi ile değiştirmeyi içeren stratejidir.

4. Kültürel Ödünçleme: Bu strateji kültüre özgü olguların aktarımında yaygındır. Kaynak kültürdeki bir ifadenin hedef dile aktarımında kaynak dildeki ifadenin aynen aktarımıdır. Bu stratejide kültürel öğeler ödünç alınmaktadır denilebilir.

5. Açımlama (Paraphrase): Kaynak dildeki öğenin hedef dilde ifadesi için hedef dilde farklı formda kelime üretme işlemidir. Açımlama stratejisinde kaynak dilde tek bir kelime ile ifade edilen durum hedef dilde bir söz öbeği şeklinde aktarılabilir. Uzak kültürler arasında yapılan çeviri sırasında ortaya çıkan bir yöntemdir.

6. Çıkarma (Omission): Çeviri sırasında kaynak dilde yer alan bir kelime, ifade veya deyimin hedef dile aktarılırken çıkarılması işlemidir. 
Yayınevinin uygun görmediği ya da gereksiz bulduğu kısımların çıkarılması da bu yöntemle ifade edilebilir. Baker, bu stratejinin çok katı bir uygulama olarak görülse de bazı bağlamlarda hedef dile aktarılırken bir kelime veya ifadeyi çevirmemenin zararı olmayacağını düşünmektedir.

7. Açıklama (Illustration): Kaynak dilde geçen sözcük ya da ifadeye eşdeğer bir karşılık bulunmadığında yararlı olabilecek bir yöntemdir. Kaynak dilin aktarımı sırasında hedef dilde dipnot ya da sonnot olarak kısa açıklamaların verilmesi yöntemidir. Aksan, Arapçadan alınma 'gamze' sözcüğünün hem yanaklarda gülümserken oluşan çukurluk hem de eski şiirde süzgün, anlamlı ve etkili yan bakış anlamlarında kullanıldığını bildirir. Bu gibi bir anlamı herhangi bir yabancı dile çevirirken açıklama gibi yollara başvurulması gerektiğini vurgular (Aksan, 2015, s. 76).

Yukarıda ele aldığımız stratejiler dışında Venuti'nin (Venuti, 2004, ss. 20-21) ortaya koyduğu 'yabancılaştırma ve yerlileștirme stratejilerinin yanında ekleme, standartlaştırma gibi isimlerle nitelenen farklı yöntemler bulunmaktadır. Çeviri stratejilerinin bazıları isim olarak faklı olsa da aslında benzer görüşler içermektedir. Örneğin Vinay ve Darbelnet tarafindan ortaya konulan ödünç alma yöntemi ile Baker'in kültürel ödünçleme stratejisi çeviri sırasındaki benzer işlemi nitelemektedir.

\section{Kaynak Eser عذراء جاكرتا ('Azrâ'u Câkartâ) Adlı Romanın İncelenmesi}

Bu bölümde incelenmiş olan roman, Arapçadan Türkçeye Ali Nar ve Mehmet Nuri Çalışkan tarafından aktarılmıştır. Ali Nar’ın çevirmiş olduğu eserin ilk baskısı 1977 yılında yayımlanmış olsa da, farklı bir yayınevi tarafından basılan yeni baskısına ulaşılmış, ancak diğer yazarın çevirdiği eserin yeni baskısına ulaşılamamıştır.

Romanda, Endonezya'da 1960'l1 y1llarda komünist partisinin emelleri, gerçekleştirmeye çalıştıkları darbe teşebbüsü ve bunun karşısında duran toplumun çektikleri anlatılmaktadır. Ayrıca romanın başkahramanı olan üniversite öğrencisi Fatma'nın cesurca dik duruşu ve partinin planlamış olduğu darbenin karş1sında durarak bu girişimin başarısız olması için çalıştığı ve sonunda bir partili tarafindan öldürüldüğü konu olarak işlenmektedir. 
Modern Arap edebiyatı dönemi yazarı Necîb el-Kîlânî, romanlarında genellikle tarih içinde yaşanılan İslami olayları, Müslümanların dünya üzerindeki durumunu, dünyanın farklı bölgelerinde yaşayan Müslümanların maruz kaldığ 1 sıkıntıları ve Mısır toplumunu konu olarak işlemeye gayret göstermiştir. Eserlerinden dolayı çeşitli ödüllere layık görülen Kîlânî, İslami edebiyat kavramı çerçevesinde de adına sıkça rastlanılan bir isimdir. Kîlânî, 1 Haziran 1931'de Mısır'ın kuzeyinde yer alan el-Ğarbiyye iline bağlı Ziftâ şehrinde bulunan Şerşâbe köyünde doğmuştur. Kîlânî, dini eğitim için henüz dört yaşında iken köy okuluna gittiğini, bundan sonra da ilkokul eğitimini köyünde aldığını belirtir. Henüz küçük yaşlarda Menfalûtî, Rafi ‘î, Şevki'nin divanı ve tiyatrolarını, Tâhâ Huseyn'in eserlerini okumaya çalıştığını ifade eder (el-Kîlânî, 2016, s. 18,19). Kîlânî, 1951 yılında Kahire Üniversitesi Tip Fakültesi'ne kaydolmuş ve üniversite okurken 4.sınıfta İhvan grubuna katıldığından dolayı, siyasi davalardan birinde hapse mahkûm edilmiştir. Bu süre zarfında 'Eğâni'l-Ğurebâ' adlı şiir koleksiyonunu toplamış ve Eğitim Bakanlığı tarafından ödüllendirilen 'et-Tarîku't-Tavîl' adlı romanını kaleme almıştır (Abdulhâlik, 2010, s. 68,69). Üniversite eğitiminin kalan kısmını serbest kaldıktan sonra tamamlamış. İlk önce memleketinde doktorluk görevini ifa eden ve 1967 'de Kuveyt'e, sonra da Dubai'ye giden Kîlânî, sağlık müdürlüklerinde çeşitli görevlerde bulunmuş ve son olarak da Birleşik Arap Emirliklerinde Sağlık Bakanlığında Sağlık-Kültür müdürü olarak görev yapmıştır (el-'Arînî, 2005, s. 14). İslami edebiyatta adından söz ettiren ve başta edebi türlerde olmak üzere çeşitli konularda yazılar kaleme alan Kîlânî, 6 Mart 1995’te Kahire'de vefat etmiş̧ir.

\section{Kaynak ve Hedef Dil Metinlerin Karşılaştırmalı Olarak İncelenmesi}

Kaynak ve hedef dil metinlerinin karşılaştırılmasındaki amaç hata avc1lığı değildir. Çevirmenlerin çeviri sırasında hangi yöntemleri tercih ettiklerini, çevirilerinde kaynak metne mi yoksa hedef dil normlarına mı bağlı kalarak çeviri yaptıklarını değerlendirmektir. Bu değerlendirmeler sonucunda da çeviri alanında daha iyi çevirilerin ortaya çıkmasına katkıda bulunmak hedeflenmektedir. Çünkü çevirmenlerin, yapılan çevirilerdeki tercih etmiş olduğu yöntemler, ister zorun- 
lu ister tercihen olsun, hedef metnin hedef dil kültüründe kabul edilebilirliği ve okunabilirliği üzerinde oldukça etkilidir. Bunun yanında çevirmenlerin, çeviri s1rasında bazen bilinçli bazen de bilinçsiz olarak yaptı̆̆ değişiklikleri görebilmek, başka çevirmenlerin çeviri alanında ortaya koyacakları yapıtları da etkileyecektir. Bu yüzden kaynak ve hedef dil metinlerinin karşılıklı olarak belirli sınırlar içinde değerlendirilmesinin çeviri alanına katkı sağlayacağı düşünülmektedir.

Çalışmamızın bu bölümünde kaynak metin yazarı Kîlânî’nin yukarıda belirtmiş olduğumuz romanının iki farklı çevirmen tarafından Türkçeye aktarılırken hangi çeviri stratejilerini tercih ettikleri karşılaştırmalı olarak incelenmiştir. İnceleme sırasında Necîb el-Kîlânî’nin عذراء جاكرتا ('Azrâ’u Câkartâ-Cakartalı Kız) roman1, 'kaynak metin' olarak yer almıştır. Ayrıca hedef metin-1 (H.M.1) olarak Ali Nar tarafından 'Cakartalı Kız' adıyla çevrilen eser; hedef metin-2 (H.M.2) olarak da M. Nuri Çalışkan tarafından 'Cakartalı Mücahide' başlığıyla aktarılan çeviri eser kastedilmektedir. İnceleme yapılırken kaynak metinden örnekler, hedef metinlerdeki karşıllklarıyla çeviri stratejileri açısından değerlendirilmiştir.

Çeviri eserlerin henüz başlığına bakıldığında çevirmenlerin başlık seçiminde farklı tercihlerde bulunduğu göze çarpmaktadır. Arapça "عذراء" kelimesi Türkçede 'bakire, kız' sözcükleri ile karşılanır. H.M.1 yazarı, romanın başlığında sözcüğü sözcüğüne çeviri yöntemini tercih ederek 'Cakartalı Kız’ olarak çevirmişken; H.M.2 yazarı, 'Cakartalı Mücahide’ başlı̆ıııı kullanarak romanın olay örgüsünden etkilenmiş bir bakıma özelleştirme yoluna gitmiştir. 
Örnek 1:

\begin{tabular}{|c|c|c|}
\hline & Kaynak Metin & \multirow[b]{2}{*}{$\begin{array}{r}\text { Çeviri } \\
\text { Stratejisi }\end{array}$} \\
\hline & متناول الزعيم الكأس للمرة الخامسة، ومع ذلك فقد بقي محتفظا بتو ازنه، متمالكا لأعصابه، & \\
\hline H.M.1 & $\begin{array}{l}\text { İydid, kadehini beşinci kez boşalttı. Buna rağmen hala dengesi } \\
\text { bozulmamıştı. Sinirlerine hâkimdi. Gözleri geçici bir neşeyle } \\
\text { parlıyordu. Yüzünde sıkıntı ve kederden iz yoktu. Orta boylu tatlı } \\
\text { esmer, tam anlamıyla tipik bir Endonezyalıydı (Nar, 2016, s.7). }\end{array}$ & $\begin{array}{r}\text { Ödünç Alma } \\
\text { Özelleştirme } \\
\text { Kültürel } \\
\text { İkame } \\
\text { Sözcüğü } \\
\text { sözcüğüne }\end{array}$ \\
\hline H.M.2 & $\begin{array}{l}\text { İydid, kadehini beşinci defa boşaltmış olmasına rağmen, dengesini } \\
\text { hala yitirmemişti. Sinirlerine de aynı ölçüde hâkimdi. Gözlerinin } \\
\text { hissedilir ölçüde neşeyle parlaması gibi, yüzünde sıkıntı ve kederden } \\
\text { de iz yoktu. Orta boylu, esmer çehresiyle tipik bir Endonezyalıydı } \\
\text { (Çalışkan, 1993, s.5). }\end{array}$ & $\begin{array}{r}\text { Ödünç Alma } \\
\text { Özelleştirme } \\
\text { Kültürel } \\
\text { İkame } \\
\text { Sözcüğü } \\
\text { sözcüğüne }\end{array}$ \\
\hline
\end{tabular}

Herikihedefmetin yazarı, çeviri sırasındabenzer stratejileriuygulamışlardır. Kaynak metinde 'الزعيم' (lider) sözcüğü, her iki yazar tarafından romanın konusuna bağlı olarak 1960'lı yıllarda Endonezya'da yaşamış olan dönemin Endonezya Komünist Partisi lideri 'Dipa Nusantara Aidit' ismini ödünç alma stratejisi ile Türkçe sesletime uygun olacak şekilde 'İydid' diye aktarmışlardır. Her iki hedef metin yazarının bu işlemi çevirinin genelinde uyguladıkları görülmüştür. Örneğin kaynak metinde geçen 'الرئيس' sözcüğünü 'başkan' olarak çevirmek yerine, dönemin başkanı olan 'Sukarno’nun ismini kullanmayı tercih etmişlerdir. Kaynak metinde 'تناول (bir şey yemek ya da içmek, almak)' olarak geçen ifadeyi 'kadehi boşaltmak' anlamında çevirmeyi tercih etmiş olsalar da, aslında Türkçede 'beşinci kadehini içti ya da argo olarak beşinci kadehini devirdi' ifadelerini kullanmaları eşdeğerlik açısından daha uygun olabilirdi.

'Tipik bir Endonezyalıydı' ifadesini de her iki çevirmen Mona Baker'in ortaya koymuş olduğu özelleştirme (alt anlamlı) çeviri yöntemi ile çevirmişlerdir. Kaynak metinde geçen 'آسيوي (Asyalı)' sözcüğünü romanın konusunda bağl1 olarak 'Endonezyalı' olarak çevirerek özelleştirme stratejisini tercih etmişlerdir. 
Bunun yanında çevirmenler, örnekteki bazı sözcüklere sözcüğü sözcüğüne çeviri anlayışını uygulamışlardır. Ayrıca H.M.1 yazarı, çevirisinde Arapçanın virgül özelliğini hedef metinde kısa cümleler şeklinde çevirerek ortaya koymuşken, H.M.2 yazarı bazı cümleleri bağlaçlarla bağlayarak birleştirme yoluna gitmiştir. Örnek 2:

\begin{tabular}{|c|c|c|}
\hline & Kaynak Metin & \multirow[b]{2}{*}{$\begin{array}{r}\text { Çeviri } \\
\text { Stratejisi }\end{array}$} \\
\hline & ـ أود أن أقابله. (s.21). & \\
\hline H.M.1 & $\begin{array}{l}\text { Hacı Muhammed İdris güldü ve: 'Dünyanın beşte dördü, şu veya bu } \\
\text { yolla aldatılmıştır.' } \\
\text { - Karşılı̆̆ını göstermek istiyorum (s.19). }\end{array}$ & $\begin{array}{r}\text { Sözcüğü } \\
\text { sözcüğüne }\end{array}$ \\
\hline H.M.2 & $\begin{array}{l}\text { Hacı Muhammed gülümsedi ve ekledi: Dünyanın beşte dördü, şu } \\
\text { veya bu yolla aldatılmıştır bilirsin. } \\
\text { - Karșllı̆ını vermek istiyorum (s.19). }\end{array}$ & $\begin{array}{r}\text { Sözcüğü } \\
\text { sözcüğüne } \\
\text { Ekleme }\end{array}$ \\
\hline
\end{tabular}

Her iki hedef metin yazarı örnek metni sözcügü sözcüğüne çevirmiştir. Kaynak metinde geçen 'şu veya bu yolla' ifadesinin aynı şekilde çevrilmesi, hedef dil kültürüne pek uygun bir ifade olmamıştır. Onun yerine hedef dilde daha çok karşılaşılan ‘öyle ya da böyle, bir şekilde’ gibi olasılık bildiren ifadelerin kullanılması daha uygun olabilirdi. Ayrıca H.M.2 yazarı, hedef dil metninde örnek cümlenin sonuna 'bilirsin' ifadesini eklemeyi tercih ederek kaynak metin durum bağlamını hedef metne yansıtmaya çalışmıştır.

Çevirmenler, kaynak metinde geçen ' قابل bir konuyu konuşmak ya da görüşmek için bir araya gelmek, karşılaşmak, karşısında olmak' anlamlarına gelen sözcüğü ve Arapça kaynak metinde de 'onunla görüşmek/karş1laşmak' istiyorum anlamındaki ifadeyi, 'karşılı̆̆ını vermek/göstermek' anlamında aktararak hedef metne kaynak metinden farklı bir anlam yüklemişlerdir. Her ne kadar kaynak metindeki fiilin 'karşılık vermek' anlamı olsa da metnin bağlamında bu anlamda kullanılmadığı anlaşılmaktadır. Her iki çevirmenin yapmış olduğu çeviri hedef metinde anlaşılamamaktadır. Bu durum da, hedef metnin okunabilirliğini olumsuz etkilemiştir. 
Örnek 3:

\begin{tabular}{|c|c|c|}
\hline & Kaynak Metin & \multirow[b]{2}{*}{$\begin{array}{r}\text { Çeviri } \\
\text { Stratejisi }\end{array}$} \\
\hline & ابتسم حاجي محمد، وقال: - أرى أن ذهابك عديم الجدوى (s.20). & \\
\hline H.M.1 & $\begin{array}{l}\text { Hacı Muhammed gülerek dedi ki: } \\
\text { - Görüyorum ki boşa kürek sallıyorsun (s.19). }\end{array}$ & Eşdeğerlik \\
\hline H.M.2 & $\begin{array}{l}\text { Hacı Muhammed gülerek kızına yöneldi: } \\
\text { - Görüyorum ki boşa kürek sallıyorsun (s.18). }\end{array}$ & $\begin{array}{r}\text { Eşdeğerlik } \\
\text { Ekleme }\end{array}$ \\
\hline
\end{tabular}

Her iki çevirmen kaynak metinde geçen birebir çeviri ile 'gidişinin faydas1z olduğunu düşünüyorum/boşuna gidersin diye düşünüyorum' anlamına gelen ifadeyi, Türkçede gerçekleşmeyecek bir iş uğrunda boşuna çaba sarf etmek anlamında kullanılan ‘boşa küre çekmek' deyimiyle vererek eşdeğerlik yöntemini, Newmark'ın deyimiyle iletişimsel çeviri yöntemini uygulamıştır. Çevirmenler, ' أرى fiilinin sözlükteki ilk anlamını kullanarak sözcüğü sözcügüne bir anlam vermeyi tercih etmiş olsalar da kaynak metnin anlamını ve etkisini hedef metne yansıtmışlardır. Ayrıca fiilin 'düşünmek' anlamını kullanarak da benzer etki verilebilirdi. H.M.2 yazarı, kaynak metinde geçen 'Hacı Muhammed gülümsedi ve şöyle dedi' cümlesini değiştirmeyi tercih etmiştir. Ayrıca kaynak metinde 'yönelmek' anlamında bir sözcük olmamasına rağmen hedef metne eklemiş, kaynak metinde yer alan 'dedi, söyledi' anlamındaki sözcügü de çıkarmıştır. 
Örnek 4:

\begin{tabular}{|c|c|c|}
\hline & Kaynak Metin & \multirow[b]{2}{*}{$\begin{array}{r}\text { Çeviri } \\
\text { Stratejisi }\end{array}$} \\
\hline & 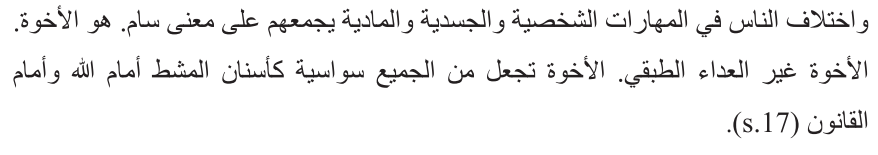 & \\
\hline H.M.1 & $\begin{array}{l}\text { Ayrıcalıklar, kişisel beceri, bünye ve madde açısındandır. Onu da din } \\
\text { harika bir mefhumda toplar. Bu kardeşliktir. Kardeşlik sınıf } \\
\text { düşmanlığından başkadır. Kardeşlik bütün toplum fertlerini 'Allah ve } \\
\text { kanun önünde bir tarağın dişleri gibi eşit görür' (s.16). }\end{array}$ & $\begin{array}{r}\text { Sözcüğü } \\
\text { sözcüğüne } \\
\text { Külttürel } \\
\text { ödünçleme }\end{array}$ \\
\hline H.М.2 & $\begin{array}{l}\text { Ayrıcalıklar ise kişisel yetenek ve kabiliyet, bünye ve madde } \\
\text { açısındandır. Onları da din, oldukça güzel bir kavram altında } \\
\text { toplamaktadır. Bu kavram da kardeşlik kavramıdır. Kardeşlik, sınıf } \\
\text { düşmanlığını yok eden en etkili güçtür. Kardeşlik bir toplumun üyelerini } \\
\text { bir tarağın dişleri gibi eşit kılar (s.16). }\end{array}$ & $\begin{array}{r}\text { Sözcüğü } \\
\text { sözcüğüne } \\
\text { Kültürel } \\
\text { ödünçleme } \\
\text { Çıkarma }\end{array}$ \\
\hline
\end{tabular}

Her iki hedef metin yazarı bu örnekte birebir çeviriyi tercih etmişlerdir. Ancak kaynak metinde geçen 'مö' sözcügünü aynı şekilde aktarmaları hedef metinde anlaşılmamaktadır. Oysa Arapçadaki bu sözcüğün karş1lığı olarak 'maddi' sözcügü kullanılabilirdi. Çünkü kaynak metindeki cümlede 'insanlar, kişisel beceri, fiziksel ve maddi durum olarak farklıdırlar' gibi bir anlam vardır. H.M.1 yazarının 'onu da din harika bir mefhumda toplar' cümlesi hedef metinde muğlak bir anlam barındırmaktadır. Çünkü kaynak metinde 'insanları kardeşlik gibi yüce bir mana içerisinde bir araya getirir' anlamında cümle vardır. H.M.1'de yer alan 'onu da' ifadesinin kaynak metinde yer alan hangi ifadeye karşılık olarak aktardığı anlaşılamamaktadır. Ayrıca her iki çevirmen, çevirilerinde 'tarağın dişleri gibi eşit olmak' ifadesini kültürel ödünçleme yöntemi ile aktarmayı tercih etmiştir. Bu cümlede rivayet edilen ' الناس سواسية كأسنان المشط، '“el-Mevsû'atu'ş-Şâmile”,2018) Hadis-i Şerif'ine de göndermede bulunulmuştur. Hadis-i Şerif'in birebir çevirisi şöyledir: 'İnsanlar bir tarağın dişleri gibi eşittir. Arap olanın Arap olmayana bir üstünlüğü yoktur. Üstünlük ancak takvadadır.' Türkçede de bu Hadis-i Şerif incelendiğinde genellikle benzer şekilde çeviri yöntemi ile çevrilmiştir. Oysa Türkçede 'tarağın 
dişleri gibi eşit olmak' deyimi kullanılmamaktadır. Bunun yanında H.M.2 yazarı kaynak metindeki 'Allah katında ve kanun önünde' anlamına gelen ifadeyi çıkarmış ve kaynak metinde yer almayan 'en etkili güçtür' ifadesini eklemiştir.

Örnek 5:

\begin{tabular}{|c|c|c|}
\hline & Kaynak Metin & \multirow[b]{2}{*}{$\begin{array}{r}\text { Çeviri } \\
\text { Stratejisi }\end{array}$} \\
\hline & 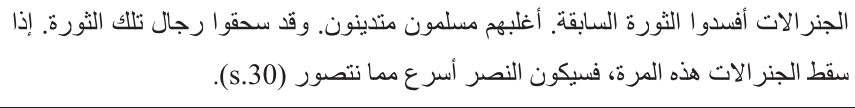 & \\
\hline H.M.1 & $\begin{array}{l}1948 \text { devrimini generaller bozdu. Dindar Müslümanlar da onları yendi. } \\
\text { O sefer Amir Şerafeddin'in adamları ezilmişti. Bu sefer generaller } \\
\text { bertaraf edilirse umduğundan çok çabuk başaracağız (s.26). }\end{array}$ & $\begin{array}{r}\text { Çıkarma } \\
\text { Ekleme } \\
\text { Değiştirme }\end{array}$ \\
\hline H.M.2 & $\begin{array}{l}1948 \text { devrimini generaller bozmuştu. Ayrıca dindar insanlar da onları } \\
\text { ezip geçmişti. Bu sefer generaller ortadan kaldırılırsa sonuca çok daha } \\
\text { çabuk ulaşılır herhalde (s.27). }\end{array}$ & $\begin{array}{r}\text { Çıkarma } \\
\text { Ekleme } \\
\text { Değiştirme }\end{array}$ \\
\hline
\end{tabular}

Her iki çevirmen de yukarıdaki örnekte kaynak metinde yer almayan bazı ifadeleri hedef metne eklemeyi tercih etmiştir. Örneğin kaynak metinde 'önceki devrim' ifadesi yer alırken çevirmenler, 1948 devrimi diye aktarmayı tercih ederek tarihi bir bilgi eklemişlerdir. Ayrıca H.M.1 yazarı, kaynak metinde yer almayan özel bir ismi de çeviri metnine eklemiştir.

Her iki hedef metinde kaynak metinde yer alan 'çoğu dindar Müslümanlardı' 'أغلب، 'أبل ifadesi yer almamaktadır. Arapçada 'çoğu, büyük kısmı' anlamında kullanılan sözcüğü hedef metinlerden çıkarılmıştır. Hedef metinlerde bir anlam karmaşası vardır. Çünkü kaynak metinde 'çoğu dindar Müslüman generaller devrimcileri hezimete uğrattı' anlamına gelen cümle değiştirilmiş, bu da anlamı etkilemiştir. Kaynak metinde 'çoğu dindar Müslümanlardı' diye kastedilen devrimin başarısız olmasına sebep olan generallerdir. Ancak hedef metinde böyle bir anlam yer almamaktadır. Çeviride kullanılan 'onları' zamiri de anlam karmaşasına yol açmıştır. Ayrıca kaynak metnin son cümlesinde 'zafer, hayal ettiğimizden daha hızlı gerçekleşecek' gibi bir anlam içeren cümleyi, her iki çevirmen değiştirerek aktarmayı tercih etmiş̧ir. H.M.1 yazarı, cümleyi ‘çok çabuk başarmak' ifadesi ile karşılamışken, H.M.2 yazarı, 'sonuca daha çabuk ulaşmak' şeklinde aktarmıştır. 


\begin{tabular}{|c|c|c|}
\hline \multicolumn{2}{|r|}{ Kaynak Metin } & \multirow[b]{2}{*}{$\begin{array}{r}\text { Çeviri } \\
\text { Stratejisi }\end{array}$} \\
\hline & 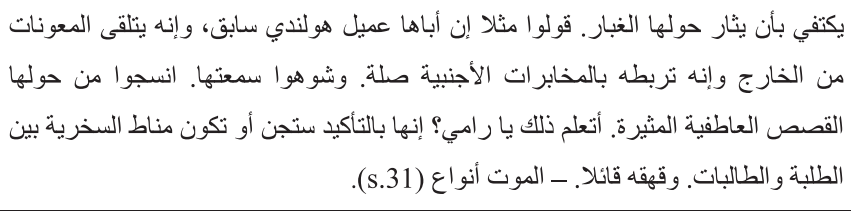 & \\
\hline H.M.1 & $\begin{array}{l}\text { Onun çevresinde toz koparmak yeter, mesela dersiniz ki; babası, } \\
\text { Hollandalıların eskiden beri ajanıymış ve dışardan da şu an yardım } \\
\text { görüyormuş. CIA'dan da maaş alıyormuş. Laf atın, çeşitli aşk } \\
\text { maceraları olduğunu yakıştırın. Öğrendin mi şimdi Rami? Böylece o } \\
\text { mutlaka ya kendini hapseder ya da talebeler arasında eğlence konusu } \\
\text { olur. Ve İydid kahkahayla ilave etti. - Ölümlerden ölüm beğensin! } \\
\text { (s.27). }\end{array}$ & $\begin{array}{r}\text { Kültürel } \\
\text { ikame } \\
\text { Değiştirme } \\
\text { Özelleştirme }\end{array}$ \\
\hline H.M.2 & $\begin{array}{l}\text { Onun çevresindeki insanlar arasında gürültü koparmaya bakın. Mesela } \\
\text { babasının Hollandalıların ajanı olduğunu, CIA'den maaş aldığını falan } \\
\text { etrafa yayın. Ayrıca çeşitli aşk masalları da uydurabilirsiniz. Şimdi } \\
\text { taktikleri anladın değil mi Rami? Böylece onun talebeler arasında } \\
\text { kahkaha konusu olacağını düşünen İydid, kahkaha ile güldü: - } \\
\text { Ölümlerden ölüm beğensin o zaman (s.28). }\end{array}$ & $\begin{array}{r}\text { Kültürel } \\
\text { ikame } \\
\text { Ekleme } \\
\text { Değiştirme } \\
\text { Çıkarma } \\
\text { Özelleştirme }\end{array}$ \\
\hline
\end{tabular}

H.M.1 yazarı, değiştirme yöntemini uygulayarak Türkçedeki 'toz kaldırmak, ortalığı karıştırmak' anlamında 'toz koparmak' ifadesini hedef metinde kullanmıştır. H.M.2 yazarı da, aynı ifadeye ekleme stratejisini kullanarak 'insanlar' sözcügünü eklemiş ve kaynak metindeki cümlenin anlamını, hedef dilde karışıklık oluşturmak anlamında da kullanılan 'gürültü koparmak' ifadesiyle vermeye çalışmıştır. Her iki çevirmen kaynak metinde yer alan 'yabancı istihbaratlar' ifadesini de somut bir şekilde 'CIA' olarak hedef metne aktararak değiştirme stratejisini uygulamışlardır. Böylelikle de kaynak metindeki genel bir ifadeyi özelleştirme yöntemi ile aktarmışlardır.

Kaynak metinde geçen 'ya çıldıracak ya da öğrenciler arasında alay konusu olacak' anlamındaki cümlenin ilk bölümünü, H.M.1 yazarı 'kendini hapsedecek' şeklinde aktarırken, H.M.2 yazarı bu cümleye çıkarma stratejisini uygulamıştır. Hedef metinlerde yer alan 'eğlence konusu/kahkaha konusu olmak' ifadeleri de 
hedef metin kültürüne uygun ifadeler olmamıştır. Ayrıca her iki çevirmen kaynak metinde geçen sözcüğü sözcüğüne çeviride 'ölüm çeşitlidir' gibi bir ifade içeren cümleyi, kültürel ikame stratejisi ya da Newmark' in deyimiyle iletişimsel çeviri yöntemiyle ‘ölümlerden ölüm beğensin' şeklinde çevirmiştir.

\section{Örnek 7:}

\begin{tabular}{|c|c|c|}
\hline & Kaynak Metin & \multirow[b]{2}{*}{$\begin{array}{r}\text { Çeviri } \\
\text { Stratejisi }\end{array}$} \\
\hline & 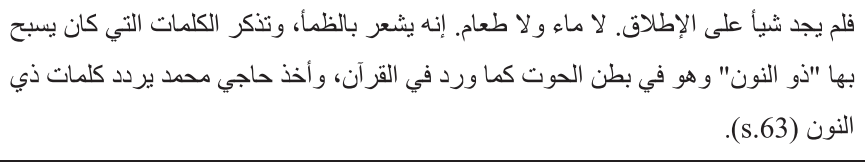 & \\
\hline H.M.1 & $\begin{array}{l}\text { Her şey kökünden yokluk. Ne su ve ne ekmek. Halbuki ciğerleri } \\
\text { yanıyor. Hemen teşbihi olan kelimeleri hatırladı: 'Zennûn!' o şimdi } \\
\text { Kur'an'da geçtiği gibi balığın karnındaydı. Hacı Muhammed başladı, } \\
\text { Zennûn sözünü tekrara (s.49). }\end{array}$ & $\begin{array}{r}\text { Sözcüğü } \\
\text { sözcüğüne } \\
\text { Değiştirme }\end{array}$ \\
\hline H.M.2 & $\begin{array}{l}\text { Su ve ekmek şu an ne kadar da özlediği şeylerdi. Ciğeri hararetten } \\
\text { yanmaktaydı. Hemen aklına her günkü tesbihi geldi: Za ennun. O } \\
\text { şimdi balığın karnındaydı, tıpkı Kur'an'da geçtiği gibi. Hacı } \\
\text { Muhammed hemen tesbihe başladı (s.52). }\end{array}$ & $\begin{array}{r}\text { Sözcüğü } \\
\text { sözcüğüne } \\
\text { Değiştirme }\end{array}$ \\
\hline
\end{tabular}

H.M.1 yazarı bu örnekte genellikle sözcüğü sözcüğüne çeviri yöntemini tercih etmiş̧ir. Fakat 'hiç bir şey yoktu' cümlesini farklı yapıyla aktarmıştır. Ardından gelen 'ne su ne de ekmek vardı' cümlesindeki bağlacın kullanımında da hata yapmıştır. H.M.2 yazarı ise kaynak metindeki 'hiçbir şey yoktu' cümlesini çıkarmış, ayrıca 'ne su ne de yiyecek bir şey vardı' ifadesini de değiştirme yöntemi ile 'su ve ekmek şu an ne kadar da özlediği şeylerdi' şeklinde aktararak kaynak metnin anlamını farklı bir yapıyla çevirmiş̦tir. H.M.1 yazarı 'susamıştı' sözcügünü 'ciğerleri yanıyor' deyimiyle aktarmayı tercih etmiştir. Ancak 'ciğerleri yanmak' deyimi Türkçede 'çok acı ve sıkıntı çekmek' anlamında kullanılan bir deyim olmakla birlikte yer yer bu kullanımına da rastlanılmaktadır. Eşdeğer ya da iletişimsel bir çeviri sağlamak isteyen çevirmen, kaynak metinde geçen ifadeyi 'susuzluktan ölmek' deyimiyle de karşılayabilirdi. H.M.2 yazarı da aynı ifadeyi, 'ciğerleri hararetten yanmaktaydı' şeklinde aktararak çeviri metne 'hararet' sözcüğünü eklemiştir. 
Her iki çevirmen Kur'an-1 Kerim'de Hz. Yunus için kullanılan bir ifade olan 'Zunnûn' sözcüğünü birebir aktararak hedef metinde anlaşılması zor bir çeviri oluşturmuşlardır. Kaynak metinde geçen ifadede birebir aktarım olarak; 'Kur'an'da geçtiği gibi balığın karnında iken Zunnûn'un yapmış olduğu tesbihatı hatırladı' cümlesi yer almaktadır. İletişimsel çeviriyi sağlamak isteyen çevirmen, kaynak metindeki ifadeyi, 'Hacı Muhammed, Kur'an'da geçtiği üzere balığın karnında iken Hz. Yunus'un çekmiş olduğu tesbihatı hatırladı' gibi benzer bir cümle ile aktarabilirdi. Çevirmenlerin tercih etmiş olduğu çeviriler, kaynak metinde gayet anlaşılabilir olarak geçen cümlenin anlaşılmasını olumsuz yönde etkilemiştir.

\section{Örnek 8:}

\begin{tabular}{|c|c|c|}
\hline & Kaynak Metin & \\
\hline & 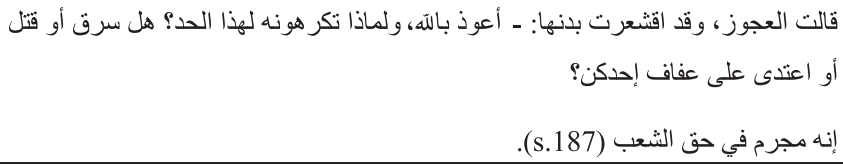 & $\begin{array}{r}\text { Çeviri } \\
\text { Stratejisi }\end{array}$ \\
\hline H.M.1 & $\begin{array}{l}\text { İhtiyar kadın, tüyleri diken diken olmuştu. } \\
\text { - Neuzu billahi. Peki bu derece adama neden hakaret ediyorsunuz? } \\
\text { Hırsızlık mı yaptı, adam mı öldürdü, yoksa birinizin namusunu mu } \\
\text { kirletti? } \\
\text { - O halka karşı suçludur (s.139). }\end{array}$ & $\begin{array}{l}\text { Kültürel } \\
\text { ödünçleme } \\
\text { Eşdeğerlik } \\
\text { Değiştirme }\end{array}$ \\
\hline H.M.2 & $\begin{array}{l}\text { Kadının tüyleri diken diken olmuştu: } \\
\text { - Neuzu billah! Adama niçin işkence ediyorsunuz kızım? Hırsızlık mı } \\
\text { yaptı? Adam mı öldürdü? } \\
\text { - O halka karşı suç işledi anne (s.154). }\end{array}$ & $\begin{array}{r}\text { Kültürel } \\
\text { ödünçleme } \\
\text { Eşdeğerlik } \\
\text { Çıkarma }\end{array}$ \\
\hline
\end{tabular}

Her iki çevirmen yukarıdaki örneği aktarırken birbirine yakın stratejiler uygulamışlardır. Çevirmenler kaynak metindeki 'قتشعر titremek, donakalmak, şok olmak' anlamlarına gelebilecek sözcügü hedef metne aktarırken hedef dil kültüründe aynı etkiyi bırakabilecek olan 'tüyleri diken diken olmak' şeklinde çevirmişlerdir. Ancak kaynak metnin yapısını değiştirmişlerdir. Kaynak metindeki cümle 'duydukları karşısında donakalan yaşlı kadın şöyle dedi' şeklinde çevrilebilirdi. Hedef metin yazarları, kaynak metinde geçen 'E'ûzu billah' olarak geçen ifadeyi, biçimsel olarak değiştirerek 'Neuzu billah' olarak verip 
kültürel ödünçleme yöntemi ile hedef metne aktarmayı tercih etmişlerdir. Bunun yerine belki de kaynak metne benzer bir etkiyi bırakmak için hedef metnin özelliklerinden yararlanarak 'kulaklarıma inanamıyorum, aman Allah'ım!' gibi ifadelerle eşdeğer bir çeviri uygulama imkânı yakalayabilirlerdi. Ayrıca 'neden ondan bu kadar nefret ediyorsunuz’ anlamındaki cümleyi de, değiştirme yöntemi ile hedef metne aktarmışladır. H.M.2 yazarı kaynak metinde geçen 'sizden birinize mi saldırdı/birinize tecavüz mü etti ya da birinizin namusuna dil mi uzattı' gibi bir anlama gelen cümleye de çıkarma işlemi uygulamıştır.

\section{Sonuç}

Kaynak metin ile hedef metinler arasında birkaç bölüm içerisinde paragraf olarak bazı farklılıkların olduğu dikkat çekmiştir. Ayrıca hedef metinlerde yer alan 'Sukarno, Subarco, Ebu Haris Nasutiyon, İrama' gibi bazı özel isimlerin kaynak metinde yer almadığı göze çarpmaktadır. Bazı isimler tarihle bağlantılı olarak hedef metinlerde yer alsa da, diğer özel isimlerin neden yer aldığı anlaşılmamıştır. Bunun yanında kaynak metinde geçen ، حزب (parti)' sözcüğünün, çevirmenler tarafından tarihi bilgiler ışığında 'komünist partisi' olarak aktarıldığı görülmektedir.

عذراء جاكرتا ('Azrâ’u Câkartâ) adlı kaynak eserle hedef metinlerden seçilmiş olan örnekler 1şı̆̆ında çevirmenlerin bilinçli ya da bilinçsiz bir şekilde tercih etmiş olabilecekleri stratejiler hakkında şu değerlendirmeyi yapabiliriz:

Genel olarak hedef metin yazarları birbirine yakın çeviri yöntemleri uygulamıştır. Ancak H.M.1 yazarının sözcüğ̈̈ sözcügüne çeviriyi, H.M.2 yazarından daha çok tercih etmiş olduğu görülmektedir. H.M.2 yazarı, yukarıdaki birçok örnekten de anlaşılacağ üzere genellikle kaynak metindeki anlamı hedef metinde farklı bir yapıda aktararak değiştirme stratejisini uygulamıştır. Bunun sonucunda da H.M.2 yazarının kaynak metni aktarırken daha fazla ekleme ve çıkarma yaptığı göze çarpmaktadır. Ancak H.M.2 yazarının çeviri metninde çıkarma yöntemini sık olarak kullanması kaynak metinde geçen ayrıntılı betimlerin yer yer hedef metne yansıtılamamasına sebep olmuştur. Bu da kaynak metnin anlamının eksik olarak aktarılmasına sebep olmuştur. 
Toury'nin eşdeğerlik anlayışı açısından hedef metinler değerlendirildiğinde H.M.1 yazarının kaynak metne yakın durarak yeterli bir çeviri anlayışı tercih ettiğini söylemek mümkün iken, H.M.2 yazarının hedef dil normlarını göz önünde bulundurarak kabul edilebilir bir çeviri oluşturmaya yönelik çaba sarf ettiği ifade edilebilir. Ancak Toury'nin de belirtmiş olduğu gibi her iki hedef metin için bunu net olarak söylemek mümkün değildir. Çünkü çevirmenler yer yer kaynak metin ya da hedef metin kültürüne yakın bir çeviri tercih etmiştir. Yani her iki çevirmen de bazen yeterli bir çeviriyi benimsemişken, yer yer kabul edilebilir bir çeviri oluşturmak için çaba göstermiştir.

Çevirmenlerin yer yer tercih etmiş oldukları stratejiler, kaynak metnin anlamının hedef metinlerde kaybolmasına sebep olmuştur. Oysa kaynak metin yazarının dili, üslubu gayet açık ve anlaşılır iken, hedef metinlerde yer yer karmaşı yapılı, anlaşılamayan cümlelerle karşılaşılmaktadır. Bu durum da hedef metinlerin anlaşılabilirliği ve okunabilirliğini olumsuz yönde etkilemiştir.

Çeviri, bir dilde yazılmış olan herhangi bir eserin başka dillerde de yaşamasına imkân sağlayan bir etkinliktir. Çeviri stratejileri de genel itibariyle bu etkinlik sırasında çevirmene yardımcı olan unsurlar olarak görülmektedir. Çeviri stratejileri, çevirmenin bazen zorunlu bazen de tercihine bağli olarak uygulanır. Çeviri sürecinde çıkarma, ekleme, uyarlama, açıklama gibi bazı stratejilerin kullanımının eleştirilmesi, uygulanan stratejilerin bir hata olduğunu göstermez. Çevirmen çeviri işlemi sırasında başvurabileceği stratejiler hakkında bilgi sahibi olduğu takdirde gerekli yerlerde bu yöntemleri kullanabilecektir. Çeviri stratejilerinin yerli yerinde bilinçli olarak kullanılması hedef metinlerin okunabilirliğini artıracak ve kabul edilebilir metinlerin oluşumunu sağlayacaktır. Bu yüzden çeviri yapacak olan çevirmenin her iki dili ve kültürü bilmesi gerekmektedir. Ayrıca çevirmen, çeviriye dair bazı kuramsal bilgilere sahip olmalı ve çeviri stratejilerini kullanabilme özelliğini kazanmalıdır. Çevirmen, kaynak ve hedef metinler arasında Nida'nın ifade ettiği gibi biçimsel eşdeğerliğin yanında dinamik eşdeğerliği de sağlamalıdır. 


\section{Kaynakça}

Abdulhalik, N. A. (2010). eş-Şahsiyetu'r-Rivâiyye beyne Ali Ahmed Bâkesîr ve Necîb el-Kîlânî. Disûk: Dâru'l-'ilm ve'l-îmân.

Aksan, D. (2015). Her yönüyle dil (6. bs., C. 1-3, C. 1). Ankara: Türk Dil Kurumu Yayınları. Aksoy, N. B. (2002). Geçmişten günümüze yazın çevirisi (1. bs.). Ankara: İmge Kitabevi.

Aktaş, T. (1996). Çeviri işlemine genel bir bakış. Ankara: Orsen Matbaacılık.

Anamur, H. (1998). Özgün bir yazınsal çeviri eleştirisi önerisi: beş düzeyli nesnel eleştiri yöntemi. Çeviribilim ve uygulamaları dergisi, (8), 1-13.

Baker, M. (2011). In Other Words: A coursebook on translation (2. bs.). USA: Routledge.

Berk, Ö. (2005). Kuramlar ışığında açıklamalı çeviribilim terimcesi. İstanbul: Multilingual Yabancı Dil Yayınları.

Çalışkan, M. N. (Çev.). (1993). Cakartalı mücahide. İstanbul: Beka Yayınları.

Dağbaşı, G. (2017). Arapçadan Türkçeye yapılan şiir çevirilerinde nitelik sorunu. 21. Yüzyılda Eğitim ve Toplum Eğitim Bilimleri ve Sosyal Araştırmalar Dergisi, 6(16), 177-195.

Dickins, J., Hervey, S. ve Higgins, I. (2017). Thinking Arabic translation. A course in translation method: Arabic to English (2. bs.). London and New York: Routledge.

Doğru, E. (2011). Dilin derin devleti deyimler (1. bs.). Ankara: Fecr Yayınları.

el-‘Arînî, A. b. S. (2005). el-İtticâhu'l-İslâmî fi e'mâl Necîb el-Kîlânî el-Kasasiyyâ (2. bs.). Riyad: Dâr Kunûz İşbîlyâ.

el-Kîlânî, N. (2015). 'Azrâ'u Cakarta. Kahire: Dâru's-Sahvâ.

el-Kîlânî, N. (2016). Muzekkiratu'l-Kîlânî. Kahire: Dâru's-Sahvâ.

el-Mevsû'atu'ş-Şâmile. (2018). İslamport. 15 Ağustos 2018 tarihinde http://islamport.com/w/ $\mathrm{fqh} / \mathrm{Web} / 1272 / 5770 . \mathrm{htm}$ adresinden erişildi.

Göktürk, A. (2016). Çeviri: Dillerin dili (12. bs.). İstanbul: Yapı Kredi Yayınları.

Grossman, E. (2017). Çeviri neden önemlidir? (A. Ece, Çev.) (1. bs.). İstanbul: Yap1 Kredi Yayınları.

How many languages are there in the world? (2018).Ethnologue Languages of The World. 10 Ekim 2018 tarihinde https://www.ethnologue.com/guides/how-many-languages adresinden erişildi.

İşler, E. ve Yıldız, M. (2008). Arapça çeviri kılavuzu. İstanbul: Elif Yayınları.

Mansûr, M. A. (2006). et-Terceme beyne'n-Nazariyye ve't-Tatbîk (2. bs.). Kahire: Dâru'lKemâl.

Munday, J. (2001). Introducing translation studies: theories and applications. London; New York: Routledge.

Nar, A. (Çev.). (2016). Cakartalı kız. İstanbul: Elif Yayınları.

Newmark, P. (1988). A textbook of translation. New York - London: Shanghai Foreign Language education Press.

Nida, E. ve Taber, C. (1982). The theory and practice of translation. Leiden: E. J. Brill.

Özyön, A. (2014). Çeviride eşdeğerlik kavramının yeniden tanımlanması ve eşdeğerlik kavramı ile ilgili sorunlar. International Journal of Languages' Education and Teaching, 2(1), 28-39. 
Raková, Z. (2016). Çeviri kuramları (Les théories de la traduction). (Y. Polat, Çev.). Ankara.

Reiss, K. (2000). Translation criticism, the potentials and limitations: categories and criteria for translation quality assessment. (E. F. Rhodes, Çev.). Manchester, U.K. : New York: American Bible Society.

Snell-Hornby, M. (2006). The turns of translation studies: new paradigms or shifting viewpoints? Amsterdam; Philadelphia: J. Benjamins Pub.

Stolze, R. (2013). Çeviri kuramları: giriş. (E. Durukan, Çev.). İstanbul: Değişim Yayınları.

Suçin, M. H. (2013). Öteki dilde var olmak: Arapça çeviride eşdeğerlik (2. bs.). İstanbul: Say Yayınları.

T. Gürçağlar, Ş. (2016). Çevirinin ABC'si (3. bs.). İstanbul: Say Yayınları.

Venuti, L. (2004). The translator's invisibility: a history of translation. London and New York: Taylor \& Francis e-Library.

Yalçın, P. (2015). Çeviri stratejileri: kuram ve uygulama. Ankara: Grafiker Yayınları.

Yazıcı, M. (2011). Çeviribilimde araştırma: disiplinlerarasılıktan disiplinlerötesiliğe. İstanbul: Multilinugal.

Yıldız, M. (2009). Necîb Mahfûz (hayat1, eserleri ve Türkçe çevirileri). Nüsha Şarkiyat Araştırmaları Dergisi, (29), 17-28.

Yıldız, M. (2017). Türkiye'de Necip Mahfuz literatürüne genel bir bakış (C. 2, ss. 78-87). Uluslararası Ortadoğu Kongresi (Dil, Tarih ve Edebiyat), sunulmuş bildiri, Ankara: Ankara Yıldırım Beyazıt Üniversitesi. 